\title{
Effects of Androgens upon DNA Synthesis in the Uropygial Glands of Quails -Immunohistochemical Studies with Bromodeoxyuridine-
}

\author{
Toshihiko Suzuki, Shozo TakahashI ${ }^{*}$ \\ and Masaaki MOROHASHI \\ College of Technology, Toyama Prefectural University, \\ Kosugi-machi, Toyama-ken 939-03. \\ * Faculty of Medicine, Toyama Medical and Pharmaceutical \\ University, Toyama-shi 930-01
}

(Received February 19, 1993)

Key words: uropygial gland, androgen, bromodeoxyuridine, immunohistochemistry, quail

Avian uropygial glands are holocrine glands organically homologous to mammalian sebaceous glands ${ }^{5)}$, moreover, like sebaceous gland, uropygial glands are said to be androgendependent ${ }^{1,7-10,12,14,16)}$. One possible method for investigating the secretory activity of uropygial glands consists in determining the frequency of mitosis in the basal cells of the secretory tubules. Conventional techniques for this purpose include the observation of mitotic activity using colchicine ${ }^{7,13,15,18)}$ and the determination of proportions of marked cells resulting from the nuclear uptake of $\left[{ }^{3} \mathrm{H}\right]$-thymidine during the period of DNA synthesis ${ }^{11,12}$. On the other hand, monoclonal anitibodies against 5-bromo-2' -deoxyuridine (BrdU), a thymidine analogue developed by GRATZNER ${ }^{4}$, permit determination of the proportion of marked cells by immunohistochemical methods ${ }^{3,17)}$ in a short period of time.

In the present study, DNA synthesis in the basal cells of the secretory tubules of the uropygial glands of castrated and androgentreated quails was investigated by immunohistochemical techniques using $\mathrm{BrdU}$. Since the shallow and deep portions of the uropygial glands are histolugically different ${ }^{6)}$, the differences between the two portions with respect to androgen dependence were also investigated.

\section{Materisls and Methods}

The experimental birds comprised 20 Japanese male quails (Coturnix coturnix japonica) four weeks of age. Ten of these quails were castrated. The experimental groups consisted of a untreated group ( $\mathrm{N}$ group), an androgen treated group ( $\mathrm{T}$ group), a castrated group (C

ウズラ尾腺の DNA 合成能に及ぼすAndrogenの影響—Bromodeoxyuridine を用いた免疫組織化学的研究一 鈴木敏彦・高橋省三**諸橋正昭*（富山県立大学短期大学部，富山県小杉町 939-03 *富山医科薬科大学医学部, 富山市 930-01) 


\section{SUzuki, Takahashi and Morohashi}

group), and a group treated with androgen after castration ( $\mathrm{C}+\mathrm{T}$ group), with 5 quails in each group. The androgen preparation used was an olive oil solution of testosterone propionate (Sigma Chemical Co.), injected daily $(0.2 \mathrm{mg} / 0.1 \mathrm{~m} l /$ day $)$ into the superficial pectoral muscle until the birds were 8 weeks of age. Upon completion of the period of treatment, a solution of $\mathrm{BrdU}$ in physical saline $(40 \mathrm{mg} / \mathrm{kg}$ body weight) was injected into the peritoneal cavity of each bird, and the uropygial gland was excised 1 hour later. The glands were fixed in $70 \%$ ethanol for 2 hours, then embedded in paraffin by the oridinary method, and $3 \mu \mathrm{m}$ sections were prepared.

The sections were processed by the immunohistochemical procedure of DoLBEARE et al. ${ }^{3}$ and Morstyn et al. ${ }^{17}$. The sections were deparaffinized and deproteinized by digestion with $0.4 \mathrm{mg} / \mathrm{ml}$ of pepsin in $0.1 \mathrm{~N}$ hydrochloric acid for 3 minutes at $37^{\circ} \mathrm{C}$ to expose the DNA. The DNA was then converted to short-chain form by treatment with $2 \mathrm{~N}$ hydrochloric acid for 60 minutes at $37^{\circ} \mathrm{C}$ to expose the $\mathrm{BrdU}$. After neutralization with $0.1 \mathrm{M}$ sodium borate, the specimens were treated with $10 \%$ normal horse serum for 20 minutes at room temperature to prevent nonspecific reactions. These specimens were incubated for 2 hours at room temperature with 100 fold diluted anti-BrdU antibody (Becton Dickinson Co.), and then for 30 minutes at room temperature with 200 fold diluted biotinized anti-mouse antibody (Vector Co.). They were followed by treatment with avidin-biotin-peroxidase complex (Vector Co.) for 60 minutes at room temperature. Coloration was carried out by using 3-3'-diaminobenzidine tetrahydrochloride, and finally the specimens were counter-stained with hematoxylin.

In the prepared sections, 5,000 basal cells in the shallow and deep portions of the secretory tubules were counted separately, and the respective proportions of cells displaying a positive reaction were determined. Student's t-test was employed for statistical processing of the data obtained.

\section{Results and Discussion}

The nuclei of the BrdU-positive basal cells in the secretory tubules were distinguished by brown staining. The observed proportions of these positively marked cells relative to the total number of basal cells counted are shown in Table 1. That is, the proportions of BrdUpositive basal cells in both the shallow and deep portions of the secretory tubules were increased by administration of androgen and decreased by castration. On the other hand, there was no significant difference in this respect between the control group and the group treated with androgen after castration. Moreover, the proportion of marked cells was higher in the deep portion as compared with the shallow portion for all the experimental groups.

As regards the difference between the proportions of marked cells observed by the $\left[{ }^{3} \mathrm{H}\right]-$ thymidine method and by the BrdU method, no reports concerning this point have appeared in connection with either avian uropygial glands or mammalian sebaceous glands, but the results obtained by the two methods are said to agree well each other in the case of mouse intestinal epithelium ${ }^{2,19}$. The results of KUSUHARA et al. ${ }^{11}$, who investigated the proportion of marked basal cells in the secretory tubules of the uropygial glands of quails 1

Table 1. Proportions of marked basal cells in secretory tubules of uropygial gland

\begin{tabular}{ccc}
\hline Group & Shallow portion & Deep portion \\
\hline $\mathrm{N}$ & $1.29 \pm 0.07^{\mathrm{a}, \mathrm{b}}$ & $5.88 \pm 0.26^{\mathrm{a}, \mathrm{b}}$ \\
$\mathrm{T}$ & $2.37 \pm 0.11^{\mathrm{a}, \mathrm{c}, \mathrm{e}}$ & $8.34 \pm 0.28^{\mathrm{a}, \mathrm{cec}}$ \\
$\mathrm{C}$ & $0.78 \pm 0.06^{\mathrm{b}, \mathrm{c}, \mathrm{d}}$ & $3.88 \pm 0.18^{\mathrm{b}, \mathrm{c}, \mathrm{d}}$ \\
$\mathrm{C}+\mathrm{T}$ & $1.20 \pm 0.13^{\mathrm{d}, \mathrm{e}}$ & $5.98 \pm 0.08^{\mathrm{d}, \mathrm{c}}$ \\
\hline
\end{tabular}

Meantstandard deviation (\%).

A letter $a, b, c, d$, or e attached to any two groups indicates a statistical difference at the significance level of $1 \%$. 
hour after administration of $\left[{ }^{3} \mathrm{H}\right]$-thymidine, almost identical with the corresponding results obtained in the present study using BrdU.

The activity of the uropygial gland is said to be controlled by sex hormones, particularly by androgens ${ }^{1,7-10,12,14,16)}$. According to the results of studies employing colchicine to investigate the frequency of mitotic figures during a specified period (5-6 hours) following administration $^{7,13,15,18)}$, the number of mitotic figures was increased by testosterone administration but decreased by castration in all cases; furthermore, administration of testosterone after castration resulted in greater mitotic activity as compared with the controls. KUSUHARA and ISHIDA ${ }^{12)}$ administered sex hormones to the domestic fowls and counted the proportion of marked cells in the deep portion of the uropygial gland 1 hour later, using $\left[{ }^{3} \mathrm{H}\right]$-thymidine; that was decreased by castration, but increased by administration of androgen after castration. Identically similar results were obtained from uropygial galnds of quails in the present study, again indicating that DNA synthesis in the basal cells of the secretory tubules of avian uropygial glands is indeed controlled by androgens. Furthermore, KUSUHARA and ISHIDA ${ }^{12}$ also reported that the rate of secretion by the uropygial gland was accelerated by administration of androgens but retarded by castration in the examination of the temporal course of the changes of DNA synthesis. In the present study, only the proportion of marked basal cells was investigated, but nevertheless the data obtained tended to corroborate the results of KUSUHARA and ISHIDA ${ }^{12)}$ concerning the effects of androgens in stimulating quail uropygial gland secretion.

Furthermore, in the present study, the deep portion of the uropygial gland displayed a higher proportion of marked cells than the shallow portion in all the experimental groups, suggesting that secretory function is intrinsically more active in the deep portion.

\section{References}

1) Bhattacharyya, S.P. and A Ghosh, The action of lutenoid on the uropygial glands of male pigeons. Folia Biologica, $8: 89-95$. 1960.

2) Chwalinski, S., C.S. Potten and G.Evans, Double labeling with bromodeoxyuridine and $\left[{ }^{3} \mathrm{H}\right]$-thymidine of proliferative cells in small intestinal epithelium in steady and after irradiation. Cell Tissue Kinet., 21 : 317 329. 1988.

3) Dolbeare, F., H. Gratzner, M.G. Pallavicini and J.W. Gray, Flow cytometric measurement of total DNA content and incorporated bromodeoxyuridine. Proc. Natl. Acad. Sci. USA, 80 : 5573-5577. 1983.

4) Gratzner, H.G., Monoclonal antibody to 5 bromo- and 5-iododeoxyuridine: A new reagent for detection of DNA replication. Science, 218 : 474-475. 1982.

5) Hodges, R.D., The Histology of the Fowl. 25-30. Academic Press. London, New York and San Francisco. 1974.

6) Ishida, K., T. Suzuki and Y. Ishiutma, Comparative histological studies on the uropygial glands of birds. Niigata Agricultural Science, 25: 129-136. 1973.

7) Ishida, K., Y. Terai, S. Kusuhara and M. YAMAGUCHI, IIormones over uropygial glands of the fowl. Jpn. J. Zootech. Sci., 45: 465-466. 1974.

8) K.AR, A.B., The hormonal influence in the normal functioning of the uropygial gland in the fowl. Anat. Rec., 99: 75-89. 1947.

9) KAR, A.B., Stimulation of the uropygial gland in the female Indian spotted munia, Uroloncha punculata (L.), due to oestrogen treatment. Nature, 164: 495-496. 1949.

10) Kar, A.B., Studies on cytochemistry of hormone action. Parts I and II. Proc. Nat. Inst. Sci. India, 16:41-47. 1949.

11) Kusuhari, S., T. Suzuki and K. Ishida, Secretory rate in uropygial gland of Japanese quail. Jpn. J. Zootech. Sci., 54 : 62-63. 1983.

12) Kusuhara, S. and K. Ishida, Influence of sexual hormones on the secretory rate in uropygial glands of cockerels. Jpn. J. Zootech. Sci., 55 : 760-764. 1984.

13) Maiti, B., Cellular dynamics of the uropygial gland in the pigeon. Folia 
Biologica, 16 : 49-54. 1968.

14) Maits, B., Influence of estrogen on the histophysiology of the uropygial gland. Arch. histol. jap., 33: 371-380. 1971.

15) MaIti, B. and A. Ghosh, Probable of androgen in the regulation of the uropygial gland. Gen. Comp. Endocrinol., $19: 527-535.1972$.

16) Montagna, W. and P.E. Parakkal, The Structure and Function of Skin. 3rd ed. 306-310. Academic Press. New York, San Francisco and London. 1974.

17) Morstyn, G., S.M. Hsu, T. Kinsella, H. Gratzner, A. Russo and J.B. Mitchell, Bromodeoxyuridine in tumors and chro- mosomes detected with monoclonal antibody. J. Clinic. Invest., 72 : 1844-1850. 1980.

18) SAHU, A., D. PAL and B.R. Maitr, Effects of sex-hormones on the uropygial gland of the female domestic duckling. Mikroskopie, $38: 204-212.1981$.

19) ShutTe, B., M.M.J. Reynders, F.T. Bosman and G.H. Blijham, Studies with anti-bromodeoxyuridine antibodies: II. Simultaneous immunohistochemical detection of antigen expression and DNA synthesis by in vivo labeling of mouse intestinal mucosa. J. Histochem. Cytochem., $35:$ 371-374. 1987. 